JSM (10) (2)
JURNAL SENI MUSIK

\title{
The Identification of Basic Music Learning Needs Students of Music Arts Study Program Solfeggio Courses
}

\author{
Nafik Salafiyah ${ }^{\bowtie 1}$, Kristian Kevin \\ Sendratasik FBS, Universitas Negeri Semarang, Jl. Raya Sekaran Gunungpati Kota \\ Semarang 50028 Indonesia
}

\begin{tabular}{ll}
\hline Article Info & Abstract \\
\cline { 2 - 2 } $\begin{array}{l}\text { Submitted: November, } \\
2021\end{array}$ & $\begin{array}{l}\text { To improve the quality of learning music in addition to ability and skills are also needed awareness } \\
\text { of the requirements behind the success of students in learning music. The first step to learn the music } \\
\text { before plunging into the skill of the instrument started by learning music basics first. To find out the } \\
\text { pevised : November,2021 } \\
\text { Accepted:December,2021 } \\
\text { to support and simplify the learning of basic music and how to cope with them. The method that } \\
\text { used in this research is qualitative method. The data collection techniques include interviews, } \\
\text { observation, and documentation. The analysis data technique that used is reduction stage, data } \\
\text { presentation, and verification or conclusion. The result of the research states that found some } \\
\text { identification requirements to learn basic music involve Milleu, Man, Method, Machine, Money, } \\
\text { and Material. Where each requirement should be understood and noticed by the students in order } \\
\text { to optimize the mastery of basic music in the Solfeggio course }\end{array}$ \\
$\begin{array}{l}\text { Keywords: } \\
\text { Solfegtification, Basic Music }\end{array}$ &
\end{tabular}




\section{INTRODUCTION}

Music Study Program set out on a mission that are develop an academic culture which conducive for the lecturer to continuously improve the professionalism and their career as the functional staff at the level of higher education. Teaching music education in a formal school. Become a music teacher in a formal school not only know the knowledge, but also can be educate the students, (Destrinelli and Wijayanti 2016) like the examples: teachers should pay more attention and train the students who are still has difficulty in reading the notation; the teacher should guide the students by walking around to supervise the students during practice singing the sheet notation which given; the teacher should prepare the learning strategies so that the below-average students want to practice singing; the teachers should have a lot to give motivation and encouragement to the students who still lack the confidence to give voice. Become an afterthought for music teacher candidate, how could it be a teacher can successfully educate students if the teacher is not educated.

Course department of music art covers two types that are theory and practice. Several practice courses among them includes solfeggio, vocal, choir, arrangement, piano, guitar, violin, inflatable wooden, inflatable metal, and percussion, (Fitriyana 2019) Solfeggio course is one of the courses which learn the basic music so it is very important to be mastered in the beginning. Solfeggio is the staple food for the people who work in the music world, music practitioner, music teacher, up to the music educators as their provision to go through the next course, one of them is the mayor of music that will be taken and become the provision to be educators as well as get into the community. The graduate results greatly affect the level of musicality development to the next level. If the students can master the solfeggio, it will be easy to take the music learning at the next level which is more difficult stage, also on the contrary.

Each individual has a different personality and interest in learning under certain condition (Febriyona, Supartini, and Pangemanan 2019). The facts speak, the students' capabilities of basic music known after taking the next practice course. It means that the students are no longer take the solfeggio course. The question is what is the matter with the solfeggio course that has been faced. Therefore, the researchers want to investigate this problem to find out what are the problems faced by the students and how large the scope of the requirements needed by the students to support and ease the basic music learning and how to cope with them.

College is one of the academic organizations that need to be controlled the teaching-learning process as well as their management, with the aim of having good quality standard. (Dr. Kaoru Ishikawa, 1989) states some of the quality standard which can be determined by the agency in order to maintain the product quality's output. On this problem which called product is the student. The quality of the product. (Sofjan Assauri, 2009:362) states that there are 6 factors that affect the quality of the product include: Men, Melliu, Machine, Material, Method, and Money. This 6M factors that will used by the researchers to find the cause factors the problem in this research.

\section{METHOD}

This research using qualitative research method which is practical action, then it is multidimensional. This research refers to the opinion of (Moleong, 2010). Based on the theory above, this research data is the explanation through the description which is words and image. The discussion of the research topic described through observation, interview, and documentation, hereinafter will be spelled out with descriptive report. Qualitative 
descriptive analysis with the approach of the flow process that the data analyzed since learning action is implemented, developed during the process learning was going on until gained the quality/professional of the learning. Data analysis technique in this research refers to the opinion of (Milles, 1992). First, the data analysis that appears in the form of words, this data is collected through observation, interviews, questionnaires and learning model. Second, this analysis consists of three flow of events that occur simultaneously, that are: data reduction, data presentation, pulling pout the conclusions/verification, (Miles and Huberman, 1992:15-21).

\section{RESULTS AND DISCUSSIONS}

Competence owned by the students at the stage of knowledge, skills, and attitudes. This basic capability was created as the foundation to do the learning process and assessment for students. Basic competence or commonly abbreviated as $\mathrm{KD}$, is the explanation of competence standard of the learners which the scope of the material is tighter compared with the competence standard of the learners. Basic competence is a number of abilities that must be owned by the students in certain course as a reference to compile the indicators of competence, (Nobertha, 2020).

Music is the beauty of sound that can be heard. This source of the sound has two types of origin, which is produced by the tools and produced by the people which called vocal. Music consists of four elements: melody, harmony, rhythm, timbre, (N. Simanungkalit, 2008:1). One of the basic music learning is solfeggio. Solfeggio is the practice of the ability of hearing or the acuity of hearing music, either the precision of rhythmic or accuracy of tone. According to Stanly which quoted by (Sumaryanto 2005) it is said to be solfeggio because the term that refers to singing of musical scale, interval, and melody exercises with sillaby zolmination that is sing the music tone by using syllable. In its development, solfeggio is not only just sing but also about hearing and reading the notes. The ability to read the notes called sight reading, the ability to hear the tones called ear training, while the ability to sing called sight singing. In other word, solfeggio is the ability to hearing music, reading music, and singing.

Learning basic music in solfeggio course has many benefits (Bahasa and Hkbp 2020). So that the students have the competence of aural at the moment of Sight Singing, Ear Training, and Writing Notation. 2). The students understanding the regular basic sounds (tone), mastering the rhythm, tone scales, intervals, chords, decorative tones, musical terms, and its signs. 3). The students read the melody and the rhythm, listen and write the interval tone.

From the result of the research has found the resistor factors as well as the needs of the students to learn the basic music. Can be identified and drawn from the theory of $6 \mathrm{M}$, that are:

1). Milleu that involve a lack of awareness of the students to learn the basic music because it's already taking advanced semester level, a low sense of musicality from the students, less stability of the sense of musicality's mastery, the habit of nothing serious at the time of learning basic music, and the lack of awareness of the students about prospective music educators or teachers where the teachers as a good role model, that's not embedded in the students themselves.

2). Man which involve the lecturer's inability to accompany the students for learning basic music outside the time of solfeggio course. Solfeggio course is only available for 2 hours in a week. Even though to mastering the solfeggio on two semesters, the students should not learn less than 6 hours a week. To cope this problem there is only one solution, that is the students are supposed to do self-learning at home outside the time of course. 
3). Method covering a viscous cultural of memorizing or imitating notation rather than mastering. The students' habit is in the safe zone who always want instant results, resisting the process. In reading, listening, and writing music notation it needs the balance of rhythmic, melodic, harmonious. Students must be considerate when these aspects, not only known by logic, but also with sense. If the musical sense is not owned yet by the students which occurs at the moment the method of prima vista or sight reading is given then make the students panic enough. Learning the basic music is required a high level of concentration to really focus and not to think about other things as well as learning time that is consistent each day.

4). Machine includes music technology or digital tools such as music program in the form of Sibelius software, guitar pro, muse score, and a helper application of learning music that is not familiar yet to the students. With these problems, then the lecturer should introduce and give a tutorial music software as well as how to operate to the students in solfeggio course. Therefore, it will simplify the students in mastering the material. (Glouca, Raharjo, and Wafa 2017) The importance of machines and technology media that are often used to support the education process, the teaching and learning process with various strategies to improve the quality of student learning

5). Money. In the moment of seeing the condition of the students that come from different background so that the need to buy musical instruments as a learning tool cannot be realized equally. If we see in this digital era, it seems like there is no one who does not have a mobile phone. The problem solving is the students are required to download the digital music application from Play Store (digital piano or a digital music instrument harmony). The principle that is most embedded in the students is, "Even if I have been able to earning money by playing music, for what is learning music basic in the solfeggio?". Find out that principles as if money make everything be the number one.
6). Material that is where a special listening notation material that goes on the material of notation dictation indeed needs a soundproof room or a kind of music laboratory. Primary (Pratama, Lumbantoruan, and Sudarman 2015) states that the process of learning solfeggio needs to be considered about the learning facilities and infrastructure. Of course, learning solfeggio is supported with adequate facilities such as soundproofing audio room (acoustic) so that students will be able to concentrate more to understanding the rhythm, melody, and chord and can be read, imitate, and create their own (the rhythm, the melody and the chord) and present it goodly. So, the results of the study will be produced to the maximum result. At the third point, in methods already described that learning solfeggio need focus and high concentration. We know that the solfeggio course room is on a regular classroom without sound proofing so the noise appearing from out the class is definitely bother the process of the course. Therefore, the students are difficult to have concentration.

\section{CONCLUSION}

The result of this research states that the researcher found some identification of the need to learn music basic that involve the aspects of Milleu, Man, Method, Machine, Money, and Material. Each need should be understood, realized, and considered by the lecturer and students in order to optimize the mastery of basic music in solfeggio course. For the lecture and institutions should strive the tools and infrastructure to support the best graduated students.

\section{REFERENCES}

Assauri, S.2009. Managemen Pemasaran Konsep Dasar dan Strategi, Edisi Pertama Penerbit. PT. Raja Grafindo Persada. Jakarta.

Dr. Kaoru Ishikawa.1989. Teknik Penuntun Pengendalian Mutu.

Bahasa, Fakultas, and Universitas Hkbp. 
2020. "Penerapan Metode Solfegio Dalam Pembelajaran Koor Emmi Simangungsong Dalam Kurikulum KKNI Program Studi Seni Musik Fakultas Bahasa Dan Seni Universitas HKBP Nommensen Terdapat Mata Kuliah Koor Dan Solfegio . Mata Kuliah Solfegio Ditawarkan Dalam Tiga ( 3 ." 10825.

Destrinelli, D., and Mei Nur Wijayanti. 2016. "Meningkatkan Kemampuan Menyanyikan Lagu Wajib Nasional Dengan Metode Solfegio Di Sekolah Dasar." Jurnal Gentala Pendidikan Dasar 1(1):159-75. doi: 10.22437/gentala.v1i1.7096.

Febriyona, Cristie, Tri Supartini, and Like Pangemanan. 2019. "Metode Pembelajaran Dengan Media Lagu Untuk Meningkatkan Minat Belajar Firman Tuhan." Jurnal Jaffray 17(1):123. doi: 10.25278/jj71.v17i1.326.

Fitriyana, Linda. 2019. "Penerapan Metode Solfegio Sebagai Upaya Meningkatkan Pembelajaran Ansambel Musik Anak Di Sekolah Dasar Negeri Minggiran Yogyakarta." Computers in Human Behavior 63(May):9-57.

Glouca, Leocana, Eko Raharjo, and Mochamad Usman Wafa. 2017. "Pemanfaatan Software Pro Tools Sebagai Media Pembelajaran." Jurnal Seni Musik 6(1):1-10.

Pratama, Tirto Agung, Jagar Lumbantoruan, and Yos Sudarman. 2015. "Korelasi Hasil Belajar Solfegio Terhadap Hasil Belajar Vokal 1 Mahasiswa Jurusan Sendratasik FBS-UNP." E-Jurnal Sendratasik FBS Universitas Negeri Padang 4(1):11-18.

Sumaryanto. 2005. "Efektifitas Penggunaan Metode Solfegio Untuk Pembelajaran Keterampilan Bermain Musik Di Sekolah Dasar (the Efektivity of Use of Solfigio
Method To Teaching of Music Skill in Elementary)." Harmonia: Jurnal Pengetahuan Dan Pemikiran Seni 6(2). doi: 10.15294/harmonia.v6i2.723.

Simanungkalit, N. 2008.Teknik Vocal Paduan Suara. PT. Gramedia: Jakarta. 